\title{
A SODIUM-CYCLE BASED ORGANISM WITH IMPROVED MEMBRANE RESISTANCE AIMED AT INCREASING THE EFFICIENCY OF ENERGY BIOTRANSFORMATIONS
}

\author{
THE U.S. DEPARTMENT OF ENERGY
}

AWARD NO. DE-FG02-97ER122214

The aim of the project was to design a functional oxidative phosphorylation system based on a $\mathrm{Na}^{+}$, rather than on a proton cycle. The rationale is to assemble in $E$. coli genes coding for a $\mathrm{Na}^{+}$-motive redox pump and genes coding for a $\mathrm{Na}^{+}$-driven ATPsynthase that reside in different organisms. A vector carrying genes coding for a functional $\mathrm{Na}^{+}$-cycle oxidative phosphorylation could then be moved to other bacteria. The presence of a sodium cycle will improve the resistance of the cell to organic solvents, detergents and other aggressive agents whose toxicity is due primarily to their causing proton leaks in the membrane. Sodium ions are more resistant to membrane leaks than are protons by several orders of magnitude. The proposed technology would be beneficial to a broad array of applications, such as improving oil desulfurization by Rhodococci and increasing the efficiency of ethanol and solvent production by bacteria.

A chimeric E. coli/P. modestum Na+ ATPase has been described in the literature, and was reported to be functionally expressed in E. coli. Therefore the focus of our exploratory project was on cloning and functionally expressing in $\mathrm{E}$. coli a $\mathrm{Na}+\mathrm{NADH}$ dehydrogenase from Haemophilus influenzae coded by the nqr 6-gene operon. After many unsuccessful attempts of expressing nqr using a variety of host vectors and E. coli strains, we finally succeeded to obtain a plasmid pHC2.2 that contained the stable nqr insert in DH5a cells.

A number of functional test were performed to learn whether a Na+ NADH dehydrogenase was being expressed from this vector. For this purpose, the plasmid was transformed into an E. coli strain lacking the two native NADH dehydrogenase loci (nuo and ndh). Recombinant cells were checked on rich medium for ampicillin resistance (carried by the backbone pSE380 vector), kanamycin and tetracycline resistance (carried by the transposon insertions disrupting the nuo and ndh genes of the host strain). All ten passed the test, indicating that the plasmid was not lost and the transposon insertions were not excised. The clones were then plated on minimal M63 medium (no sodium) with mannitol and IPTG. Growth on mannitol requires an NADH dehydrogenase, and the only possible source of this enzyme in the host deleted for NADH dehydrogenase genes would be the recombinant NQR enzyme. " Experimental plates additionally contained $20 \mathrm{mM} \mathrm{NaCl}$. None of the clones plated on regular M63 medium with mannitol showed growth, but several of the plated colonies grew on this medium supplemented with $\mathrm{NaCl}$. The NQR NADH dehydrogenase is stringently dependent upon $\mathrm{Na}^{+}$for its activity. This test indicated that the $\mathrm{Na}^{+} \mathrm{NADH}$ dehydrogenase from $H$. influenzae had been functionally cloned into $E$. coli.

Next, everted membrane vesicles were obtained from this recombinant strain by French press disruption/differential centrifugation, and the presence of the NADH dehydrogenase enzyme was assayed by following the decrease in added NADH (following absorbency at $340 \mathrm{~nm}$ ). Vesicles showed considerable NADH dehydrogenase activity in a medium with $\mathrm{Na}+$, but not without $\mathrm{Na}+$. Control vesicles from a strain lacking native or recombinant nqr had not NADH dehydrogenase activity. These

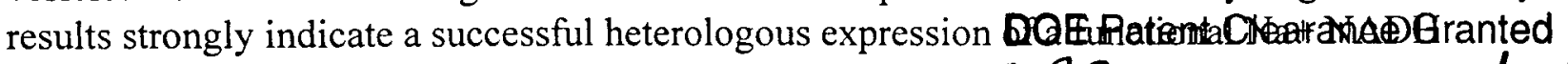
dehydrogenase. 


\section{DISCLAIMER}

This report was prepared as an account of work sponsored by an agency of the United States Government. Neither the United States Government nor any agency Thereof, nor any of their employees, makes any warranty, express or implied, or assumes any legal liability or responsibility for the accuracy, completeness, or usefulness of any information, apparatus, product, or process disclosed, or represents that its use would not infringe privately owned rights. Reference herein to any specific commercial product, process, or service by trade name, trademark, manufacturer, or otherwise does not necessarily constitute or imply its endorsement, recommendation, or favoring by the United States Government or any agency thereof. The views and opinions of authors expressed herein do not necessarily state or reflect those of the United States Government or any agency thereof. 


\section{DISCLAIMER}

Portions of this document may be illegible in electronic image products. Images are produced from the best available original document. 


\title{
A SODIUM-CYCLE BASED ORGANISM WITH IMPROVED MEMBRANE RESISTANCE AIMED AT INCREASING THE EFFICIENCY OF ENERGY BIOTRANSFORMATIONS
}

AWARD NO. DE-FG02-97ER122214

\author{
THE U.S. DEPARTMENT OF ENERGY
}

The aim of the project was to express in E. coli components that would allow for a formation of a functional oxidative phosphorylation system based on a $\mathrm{Na}^{+}$, rather than on a proton cycle. The presence of a sodium cycle will improve the resistance of the cell to organic solvents, detergents and other aggressive agents whose toxicity is due primarily to their causing proton leaks in the membrane. We have cloned and expressed the nqr operon from $\mathrm{H}$. influenzae in $\mathrm{E}$. coli. Experiments with membrane vesicles indicated the presence of the funcitonal recombinant sodium pumping NADH dehydrogenase. A gene for a hybrid $E$. coli/P. modestum ATPase was constructed which will enable to co-express a sodium ATPase together with a sodium NADH dehydrogenase in the same cells.

U.S. Department of Energy

Chicago Operations Office

Contracts Division

9800 South Cass Avenue

Argonne, Illinois 60439

\begin{tabular}{|l|l|l|l|l|}
\hline DOE & $\begin{array}{l}\text { A Sodium Cycle Based } \\
\text { Organism With Improved } \\
\text { Membrane Resistance aimed } \\
\text { at Increasing the Efficiency of } \\
\text { Energy Biotransformations }\end{array}$ & $7.15 .97-7.14 .2000$ & 520340 & $\$ 384,731$ \\
\hline
\end{tabular}

Dr. Theodore M. Liszczak

Associate Director, Grants and Contracts Administration

Tufts University

tel. 617-627-3417

fax 617-627-3673

theodore.liszczak@tufts.edu 